\title{
ASSESSMENT OF CHANGES IN THE ECONOMIC STRUCTURE OF THE TRENČÍN REGION
}

\author{
Beata Adamkovicova \\ Alexander Dubcek University in Trencin, Slovak Republic

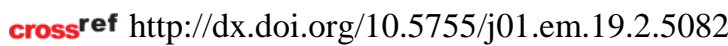

\begin{abstract}
The transformation of the centrally-controlled economy into the market one and also the attempt to join the European integration structures have initiated many problems to be tackled within the development of regions. The change of Slovak social and economic structures has had a huge impact on the initial economic regional structures. The paper objectives are to identify and assess the changes in the economic structure of the Trencin Region and its rural and transition areas. The changes in the economic structure are assessed through an absolute and relative number of employees in the economic sectors (land management, industries, civil engineering, trade and other sectors), through the number of enterprises and businesses based in the region, through the business activity encoding in itself the dynamic growth of enterprises and businesses. The impact of changes in the economic structure and business activities on the social and economic development is assessed through basic indicators such as number of unemployed people, the unemployment rate and the GDP per capita. The methodology of analysis, synthesis, benchmarking and shift-share analysis are employed to recognize the changes in the economic structure. In line with the goal of the paper it has been found that within the rural and transition areas in the Trencín region, the changes are differentiated in factors and in the results in the development as well. The results show the sectors where jobs are created. The number of businesses was increasing in the period when the research was carried out, the indices of the business activity in rural and transition areas were becoming equal slowly. The disparity between the GDP per capita created in the Trencin Region and the average Slovak GDP has grown. The Trenčin Region has had the tendency to stay behind in the economic development.
\end{abstract}

The type of the article: Research paper.

Keywords: changes of economic structure, business activities, Trenčín region, social and economic development.

JEL Classification: P25, R58.

\section{Introduction}

The transition of the centrally-controlled economy into new conditions of the market economy seems to be a very complex, long-term process that is conditioned by its commencement, its starting point Okáli (1999). The Slovak economy before the transformation process used to have some qualities that have been still conditioning its regional cohesion achievable through a coordinated approach towards achieving the goal to decrease the disparities at the level of regional development and diminishing the disparities between the poorest regions. According to Ivanová (2011) the development of regions, especially diminishing the regional disparities is conditioned by ways and forms of utilizing the potential of regions, especially by creating the conditions for utilizing this potential.

The Slovak economy has been built on the principle "type of the industry and region/area" while heavy industry and large companies operating in it used to be dominant. The large companies created some economic agglomeration with a social infrastructure with a very strong concentration of labour force. The Slovak economy used to be known for its heavy industry and running large companies (Morvay et al., 2005). The sector of agriculture has gone through a very difficult period, 
had to modify itself to the new situation at the free market while the amount of governmental subsidies decreased (Adamkovičová, 2013). At present the Slovak economy is in a new phase of its development with new opportunities, challenges and new problems.

The changes in the field of economy within the transformation process have had a significant impact on the welfare and they can be seen also in the way of life of communities and groups of population as it is stated by Gajdoš (2001) and Králiková (2006). The basic dividing line between the differentiation processes that take place in the social layers is the vertical social-economic polarization with social inequalities in individuals and families and at the same time also the horizontal social-spatial differentiation. Vertical social-economic polarization with social inequalities with individuals and families has created a new social structure of population.

According to Habánik, Masárová (2013) conditioned by the economic recession that could be traced in the indicators of the economic efficiency at the edge of the years 2008/2009 there was an economic drop accompanied by a shift in the employment.

At present the Slovak economy is in a new phase of its development with new opportunities, challenges and new problems. The long-term competitiveness of the Slovak economy is feasible according to Bielik (2008) through creating the conditions and implementation of the knowledge economy.

This paper is aimed to identify and assess what changes in the economic structure occurred in the regions of Trenčín and how these changes affected the level of economic and social development of the county and its regions.

\section{Methods}

In the research that has been carried out in the Trenčín Region and its districts divided into rural, transition and urban districts according to the methodology by Fáziková (2003), the population density criteria are employed. The degree of correlation between indicators that are applied in the rural region definition by the EU is proved to be low and statistically inconclusive according to the author. Due to this fact other criteria are not acknowledge while defining the rural type of regions. Transition regions cover 82.4 per cent of the regional area with 89 per cent out of the total population number (Trenčín, Ilava, Partizánske, Prievidza, Považská Bystrica, Púchov, Nové Mesto nad Váhom). Rural regions cover 17.6 per cent of the total area of the region with eleven per cent of the population (Myjava, Bánovce nad Bebravou). The Trenčin region covers an area that cannot be defined as an urbanized region. The process of changes in the economic structure and the business activity were assessed in the years 2005-2011 according to the following indicators:

- Absolute and relative share of employed people in the economic sectors (industry, agriculture, civil engineering, trade and other branches, where employees were accumulated in the field of public administration, financial institutions and institutions active in the tourist industry);

- The number of businesses and enterprises classified as legal entities and persons based in the regions (licensed businessmen, freelancers and farmers) who represent the economic changes;

- The business activity (BA) expressed as the equation:

$\mathrm{BA}=$ (number of businesses/number of economic active people) $\times 1000$

that expresses the dynamics of the businesses, enterprises growth.

The impact of changes in the economic structure and the business activity on the socialeconomic development can be assessed in three basic indicators, such as:

- number of the unemployed people,

- the unemployment rate,

- GDP - total and per capita. 
The changes of the economic structure are expressed by Shift-Share analysis (analysis of structural changes, Richardson, 1979, Bendavid-Val, 1991, Blair, 1995) from the equation:

$$
\triangle \mathbf{E}_{\mathrm{ir}}=\mathbf{N S}_{\mathrm{ir}}^{\mathbf{t}}+\mathbf{I M}_{\mathrm{ir}}^{\mathrm{t}}+\mathbf{R S}_{\mathrm{ir}}^{\mathrm{t}}
$$

The first part shows the growth that can be achieved if the regional industry "i" would grow as equally as the growth (decline) achieved in the national economy (National Share Component NS). The second part of the equation indicates the change of employment rate achieved in the regional industry, if the regional industry grew at the same pace as the same national economic industry (Industry Share Component - IM). The third part of the equation refers to the increase (decrease) in the regional employment rate due to the regional impulses and reflects the competitiveness of the region in the given sector (Regional Shift Component - RS).

National Share Component - NS

$$
N S_{i r}^{t}=E_{i r}^{t-1} \times\left(\frac{E_{S K}^{t}}{E_{S K}^{t-1}}-1\right)
$$

Industry Mix Component - IM

$$
I M_{i r}^{t}=E_{i r}^{t-1} \times\left[\left(\frac{E_{i S K}^{t}}{E_{i S K}^{t-1}}\right)-\left(\frac{E_{S K}^{t}}{E_{S K}^{t-1}}\right)\right]
$$

\section{Regional Shift Component - RS}

Where:

$$
R S_{i r}^{t}=E_{i r}^{t-1} \times\left[\left(\frac{E_{i r}^{t}}{E_{i r}^{t-1}}\right)-\left(\frac{E_{i S K}^{t}}{E_{i S K}^{t-1}}\right)\right]
$$

$$
\begin{array}{lll}
\mathrm{t}=\text { current time period } & \mathrm{t}-1=\text { one year ago } & \mathrm{E}=\text { employment } \\
\mathrm{i}=\text { specific industry } & \mathrm{r}=\text { specific region } &
\end{array}
$$

The structural changes are analysed with the regard to the links between the development of the industry/sector in the region and the development in the entire national economy, in industries in the national economy, and takes into account the endogenous conditions of the Trenčín Region. The relations/the ratio are expressed via the employment rate.

\section{Results}

There are more factors that have impact on the economic and social regional development. The key role in this field is played by businesses and their activities based in the regional centers and their industrial branch. The Trenčín Region covering the area of 4,501 square kilometers - 9 per cent of the total Slovak area with the population of 599,800 (11\% of the Slovak population) takes the third position among the most populated regions where 276 municipalities are based, out of them 18 have the status, have the rights of a town.

Changes in the economic structure. The transformation process has had a great impact on the economic structure of the Trenčín Region. The economy used to be represented mostly by industries such as textile and clothing industry, tire production, mechanical engineering. Another sector playing a key role within the Trenčín rural economy used to be agriculture, that together with the sector of services (national government) used to belong to the key sectors having an impact on the welfare development.

During the period that was assessed the economic structure of the Trenčín region and its districts had been undergoing significant changes: whereas in the year 2005 industries in the Trenčín region employed 40 per cent of the total number of employed people, in the years 20102011 (during two years) 20,470 jobs disappeared in the Region due to closing down the factories in 
the mechanical engineering, textile and clothing industries.

Contrary to structural changes in Slovakia, the industries in the rural areas in the Trenčín Region ensured some significant dynamics in the growth in a number of jobs due to the fact that two industrial parks based in rural areas (Bánovce nad Bebravou, Myjava) were established. The most dynamic sector in the Trenčín region, during the period assessed, used to be trade having opened the largest number of jobs $(7,300)$. During a period of time it represented a permanent growth in jobs. After an initial growing number of jobs opened in the civil engineering, the number of jobs in this field was stabilized and amounted the number 18,500. Till 1990 the sector of agriculture in the Trenčín Region could be defined as intensive one and stabilizing the social welfare in rural areas, in the years 2005-2008 the number of jobs in agriculture decreased by 1,100 and was stabilized at the number of 10,000 and since 2010 the number of employees in the agriculture and land management has increased by 620. The competitive situation in the Trenčín Region, if compared to the situation in the national economy in the period of 2005-2011, can be characterized through the method Shift-Share Analysis.

Table 1. The results of structural changes in the Trenčín Region and its areas expresses via the Shift-Share analysis

\begin{tabular}{|c|c|c|c|c|c|c|c|}
\hline \multirow{2}{*}{ Area } & \multirow{2}{*}{ Industry } & \multicolumn{2}{|c|}{ Employment } & \multirow{2}{*}{$\begin{array}{c}\text { Total change } \\
2005-2011\end{array}$} & \multirow{2}{*}{ NS } & \multirow{2}{*}{ IM } & \multirow{2}{*}{$\mathbf{R S}$} \\
\hline & & 2005 & 2011 & & & & \\
\hline \multirow{6}{*}{ Slovak Republic } & Agriculture & 119762 & 95958 & 23804 & & & \\
\hline & Industries & 556723 & 586307 & 29584 & & & \\
\hline & Civil eng. & 131199 & 166119 & 34920 & & & \\
\hline & Trade & 344777 & 365468 & 20691 & & & \\
\hline & Other industries & 845042 & 979225 & 134183 & & & \\
\hline & Total & 1997503 & 2193077 & 195574 & & & \\
\hline \multirow{6}{*}{ Trenčín Region } & Agriculture & 11569 & 10529 & -1040 & 1133 & -3432 & 1259 \\
\hline & Industries & 90142 & 76859 & -13283 & 8826 & -4036 & -18073 \\
\hline & Civil eng. & 16665 & 18537 & 1872 & 1632 & 2804 & -2564 \\
\hline & Trade & 37144 & 44453 & 7309 & 3637 & -1408 & 5080 \\
\hline & Other industries & 72607 & 80920 & 8313 & 7109 & 4420 & -3216 \\
\hline & Total & 228127 & 231298 & 3171 & 22336 & $\mathbf{0}$ & -19165 \\
\hline \multirow{6}{*}{$\begin{array}{l}\text { Transition } \\
\text { areas within } \\
\text { the Trenčín } \\
\text { Region }\end{array}$} & Agriculture & 9435 & 8651 & -784 & 924 & -2799 & 1091 \\
\hline & Industries & 81264 & 65306 & -15958 & 7956 & -3638 & -20276 \\
\hline & Civil engineering & 15235 & 16537 & 1302 & 1492 & 2563 & -2753 \\
\hline & Trade & 33914 & 40675 & 6761 & 3320 & -1285 & 4726 \\
\hline & Other industries & 65772 & 73822 & 8050 & 6440 & 4004 & -2394 \\
\hline & Total & 205620 & 204991 & -629 & 20132 & $\mathbf{0}$ & -20761 \\
\hline \multirow{6}{*}{$\begin{array}{l}\text { Rural } \\
\text { areas } \\
\text { Trenčín } \\
\text { Region }\end{array}$} & Agriculture & 2134 & 1878 & -256 & 209 & -633 & 168 \\
\hline & Industries & 8878 & 11553 & 2675 & 869 & -397 & 2203 \\
\hline & Civil engineering & 1430 & 2000 & 570 & 140 & 241 & 189 \\
\hline & Trade & 3230 & 3778 & 548 & 316 & -122 & 354 \\
\hline & Other industries & 6835 & 7098 & 263 & 669 & 416 & -822 \\
\hline & Total & 22507 & 26307 & 3800 & 2204 & $\mathbf{0}$ & 1596 \\
\hline
\end{tabular}

Source: The Slovak Office of Statistics, own calculations.

\section{Referring to the effectiveness of the national economy it can be assumed that:}

- the development of employment rate in the Trenčín Region has been different from the overall national economic development due to the diversity of disposable endogenous factors of development and the starting position of the region;

- if the industries in the Trenčín Region achieved the dynamics of opening the jobs in the national economy, then the effect of vacancies growth in the region till 2011 would represent a growth by 22.3 thousand vacancies instead of 7,171 jobs created. Most positions should have been opened in the transition regions. The results show that in the rural areas in the Trenčin Region the vacancies were created at a more dynamic pace than the jobs opened in the national economy. If the trend in the national economy had been as equal as the one in the Trenčín Region, this sector 
would have created 2,204 jobs, whereas the rural areas created 3,800 real jobs. Referring to the national economy, the rural areas in the Trenčín Region revealed themselves as competitive.

Based on the effect achieved in the industries, it can be assumed that:

- that if the development of the employment rate in the industries in the Trenčín Region went at the same pace as it went in other Slovak industries, then in the Trenčín Region in the period searched and assessed that:

- The agriculture would have had a drop in jobs - by 3,422 positions, there was a real decrease by 1,040 jobs;

- The industries would have had a decrease by 4,036 jobs (a real drop in numbers is 13,208 jobs fewer);

- In the civil engineering 2,804 vacancies should have opened - 1,872 jobs were really offered;

- The other sectors should have opened 4,420 jobs, really there were 8,313 positions offered.

Based on the above mentioned facts and numbers it can be assumed that only agriculture and other industries were competitive with the industries in the national economy.

From the point of view of the regional effect reflecting the competitiveness of the Trenčín Region with the industries forming the national economy it can be said that:

In the Trenčín Region the competitive industries were only agriculture and the sector of public administration, other sectors and industries did not have a propulsive impact and thus they were not able to induce the economic development in the region.

The structure of businesses and enterprises. Enterprises are open systems entering into horizontal and vertical relations with other businesses and their economic environment. Decisions on localization made by businesses have a huge impact on the spatial economic structure of regions and they form it at the same time (Maier, Todling, 1998).

Table 2. Businesses in numbers in the Trenčín Region

\begin{tabular}{|c|c|c|c|c|c|c|c|}
\hline \multirow[b]{2}{*}{ Region } & \multirow[b]{2}{*}{ Indicator } & \multicolumn{2}{|l|}{2005} & \multicolumn{2}{|c|}{2008} & \multicolumn{2}{|c|}{2011} \\
\hline & & $\begin{array}{l}\text { Number of } \\
\text { businesses }\end{array}$ & $\%$ & $\begin{array}{l}\text { Number of } \\
\text { businesses }\end{array}$ & $\%$ & $\begin{array}{l}\text { Number of } \\
\text { businesses }\end{array}$ & $\%$ \\
\hline \multirow{7}{*}{ 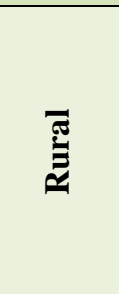 } & $\mathrm{PO}$ & 745 & 19 & 1015 & 20 & 1169 & 21 \\
\hline & FO & 3188 & 81 & 4127 & 80 & 4525 & 79 \\
\hline & Z toho: & & & & & & \\
\hline & Licensed businessmen & 2925 & - & 3915 & - & 4288 & - \\
\hline & Freelancers & 147 & - & 127 & - & 156 & - \\
\hline & Farmers & 116 & - & 85 & - & 81 & - \\
\hline & Total & 3933 & 100 & 5142 & 100 & 5694 & 100 \\
\hline \multirow{7}{*}{ 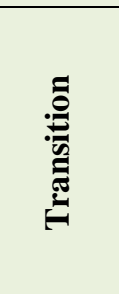 } & $\mathrm{PO}$ & 8262 & 21 & 11338 & 24 & 12804 & 24 \\
\hline & FO & 30657 & 79 & 36200 & 76 & 39726 & 76 \\
\hline & Z toho: & & & & & & \\
\hline & Licensed businessmen & 27154 & - & 34781 & - & 37909 & - \\
\hline & Freelancers & 1135 & - & 1160 & - & 1581 & - \\
\hline & Farmers & 368 & - & 259 & - & 236 & - \\
\hline & Total & 38919 & 100 & 47538 & 100 & 52530 & 100 \\
\hline \multirow{7}{*}{ 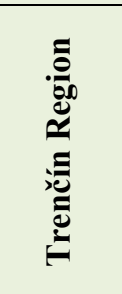 } & $\mathrm{PO}$ & 9007 & 21 & 12353 & 23 & 13973 & 24 \\
\hline & FO & 33845 & 79 & 40327 & 77 & 44251 & 76 \\
\hline & Z toho: & & & & & & \\
\hline & Licensed businessmen & 30079 & - & 38696 & - & 42197 & - \\
\hline & Freelancers & 1282 & - & 1287 & - & 1737 & - \\
\hline & Farmers & 484 & - & 344 & - & 317 & - \\
\hline & Total & 42852 & 100 & 52680 & 100 & 58224 & 100 \\
\hline
\end{tabular}

Source: The Slovak Office of Statistics, own calculations.

In the Trenčín Region by Dec. $31^{\text {st }}, 2011$ there was a total number o 58,224 enterprises and businesses, three fourth of them are persons such as licensed businessmen (80\%), freelancers (3\%) and farmers (1\%). The small and medium enterprises are dominant and play a key role in the economic structure of the Trenčín Region. The dynamics in the number of businesses was diverse in 
the given period. The number of licensed businessmen is the largest one in the given period. It can be assumed that the large number of businessmen contributes to the diversification of the economic structure. It has been proved in the practice that large companies make some employees run their own business and invoice the work done for the company as a freelancer or a businessman that is for the company more advantageous from the economic point of view. The freelancers with their specialization and their capital availability do not create input and output links to other companies. In this way the multiplication impact on the regional economic development is small, on the other hand there is a link to the social development and the diversification in jobs offer.

In the period assessed there is a slight increase in opening freelance positions - by 455 and decrease in farmers positions by 167 in rural areas, who were registered as jobless at the Office for labour and unemployed people. Medium-sized and large enterprises are aggregated into a group of legal entities. In the years 2005-2011 the number of legal entities increased by 4,966 it means an increase by 708 businesses and enterprises as legal entities per year. Middle-sized enterprises represent $24 \%$ in the economic structure. The multiplication effect in the process of development has been increasing as there are links created to other businesses and enterprises offering material inputs, storing the materials, sales and transportation, and the job offers are concentrated in an area, in a region.

The dynamics of the business number growth in the Trenčín Region is indicated by the entrepreneurial, business activities represented by the index of the business activity - BA (see Figure 1).

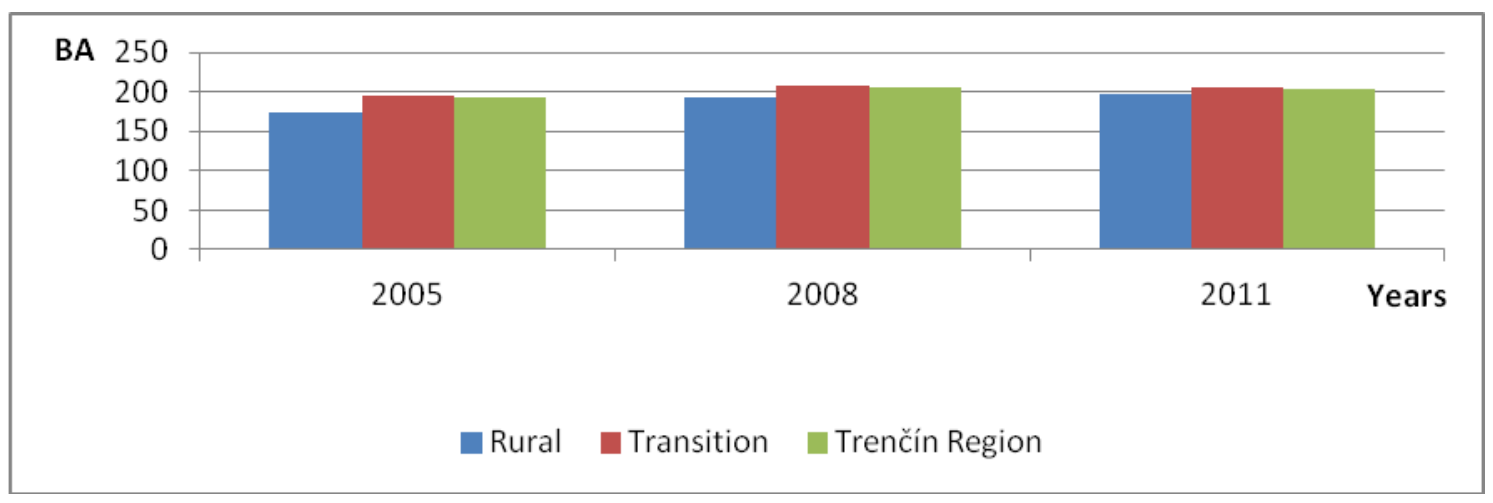

Figure 1. Index of business activity in Trenčín Region and its areas

The number of businesses in the Trenčín Region increased during the assessed period of the years 2005 - 2011, when the number of businesses per 1,000 employed people went up by $18 \%$ reaching the level of 204 businesses per 1000 employed people in the year 2011. The businesses were concentrated mostly in the transition regions. In the rural areas of the Trenčín Region 5,694 businesses were based, i.e. almost $10 \%$ out of the total number of businesses that were located in the Region. It is necessary to point out, that the structure of the businesses in rural areas did not differ from the overall regional structure. The businesses operating as legal entities were represented by $21 \%$. In the transition areas the index of the business activity was represented by the number 196 in the year 2005 and in the year 2011 it amounted the number 205 businesses per 1,000 employed people.

The impact of changes in the economic structure and in the business activity on the social and economic development. The issue of unemployment is considered to be a potential of the economic development lost in the region and it is considered to be a very severe social issue that needs re-division of newly created surplus value. 
Table 3. The unemployment rate in areas of the Trenčín Region

\begin{tabular}{|c|c|c|c|c|c|c|}
\hline \multirow[b]{2}{*}{ Region/Year } & \multicolumn{2}{|c|}{2005} & \multicolumn{2}{|c|}{2008} & \multicolumn{2}{|c|}{2011} \\
\hline & 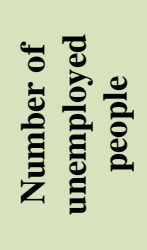 & 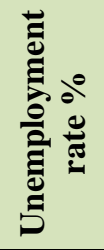 & 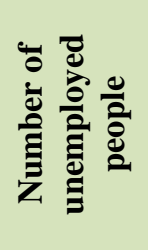 & 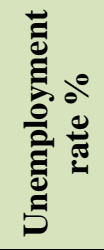 & 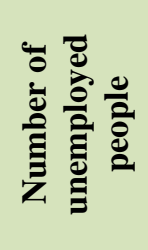 & 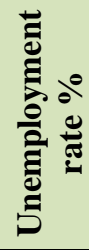 \\
\hline Rural & 2945 & 7,7 & 1765 & 4,8 & 3340 & 9,1 \\
\hline Transition & 20465 & 6,7 & 14598 & 4,5 & 29863 & 9,8 \\
\hline Trenčín Region & 23410 & 6,8 & 16363 & 4,9 & 33203 & 9,9 \\
\hline Slovak Republic & 333834 & 11,3 & 248556 & 8,4 & 399800 & 13,6 \\
\hline
\end{tabular}

Resource: The Slovak Office of Statistics, own calculations.

In the year 2005 the Trenčín Region registered a total number of 23,410 of unemployed people, $12.6 \%$ out of them were based in the rural areas. The data on the regional unemployment rate point out that the changes brought a drop in jobs between the years 2008 and 2011 when the number of jobless people was doubled in the transition and rural areas. The unemployment rate reflected the fact that a lot of people were dismissed and the jobs were dismissed too. In the year 2005 the unemployment rate reached $6.8 \%$ that was by $4.5 \%$ lower rate than the overall Slovak unemployment rate. In that year the unemployment rate in the rural areas in the Trenčin Region was substantially higher than the regional unemployment rate and reached 7.7\% .By the year 2008 the unemployment rate decreased to $4.9 \%$ in the Trenčín Region and to $4.5 \%$ in transition areas, due to the fact that industrial parks with foreign companies started to be launched into operation. Till the year 2011 the unemployment rate went rapidly up if compared to the year 2008-9.9\%. The Slovak unemployment rate was by $3.7 \%$ lower in that period.

The effectiveness of the businesses and industries and their specialization is reflected in the regional gross domestic product.

The share of the Trenčin Region in the total national GDP represented 10\% in the assessed period. With the growing number of businesses and enterprises and with the growth of GDP the share of the Trenčín Region was decreasing in the national GDP. The structural changes in the industrial structure are not directed towards the sectors with higher added value. The dynamics in GDP was lower than the average dynamics in the national economy and the Region of Trencín tended to stay behind in the economic development.

Table 4. Regional GDP in the Trenčín Region

\begin{tabular}{|l|l|c|c|c|c|}
\hline \multicolumn{1}{|c|}{ Area } & \multicolumn{1}{c|}{ Indicator/year } & Unit & $\mathbf{2 0 0 5}$ & $\mathbf{2 0 0 8}$ & $\mathbf{2 0 1 1}$ \\
\hline \multirow{2}{*}{ Trenčín Region } & GDP in total & mil. $€$ & 4855 & 6721 & 6434 \\
\cline { 2 - 6 } & GDP per capita & $€$ & 8079 & 11502 & 10744 \\
\hline \multirow{2}{*}{ Slovak Republic } & GDP in total & mil. $€$ & 49314 & 66842 & 65869 \\
\cline { 2 - 6 } & GDP per capita & $€$ & 9154 & 12365 & 12131 \\
\hline \multirow{2}{*}{ Share } & GDP Trenčín region/GDP SR & $\%$ & 10 & 10 & 10 \\
\hline
\end{tabular}

Source: Regional comparisons of the Slovak Republic 2005 - 2011, own calculations

A more appropriate indicator of assessing the level of economic development of the region is an indicator of GDP/per capita. From this point of view, in 2011 the Trenčin Region ranked the position of the countries with sub-average GDP 10,744 €; the average GDP was $€ 12,131$ The dynamics of this growing indicator outlined the fact, that the differences in the economic development between the Trenčín Region and the Slovak Republic became larger and larger. It can be assumed that the changes of the economic structure did not represent the desired economic growth. 


\section{Discussion}

In the given period the changes in the economic structure in the Trenčín Region were assessed and reflected following facts:

In the years 2005-2008 industries played the key role in the economy and at that time they employed 40\% of all labour force, in the years 2010-2011 20 thousand jobs were dismissed in the industries. The Trenčín Region used to be a very industrial region but in the given period that was assessed the region was not able to keep on the industrial production as it was expected. New industrial parks launched their operation in the rural areas so the rural areas were able to offer jobs in this region.

The structural changes in the Trenčín Region are analysed and the results show that the sector competitive with the national economy is agriculture and public administration. The both sectors belong to those ones that create the lowest added value and due this reason the Trenčín Region started to have the position behind in the economic development.

The number of businesses especially licensed businessmen has increased and resulted in drop in the unemployment rate, which in 2011 was significantly lower than the national unemployment rate in the Slovak Republic. The dynamics of the increase of the number of businesses in the rural and transition areas was almost at the equal level so the structural changes in the region contributed to the social development and not to the economic development.

The progress in jobs creation and the unemployment rate in the Trenčín Region was at the level of the social development. The changes in the direction of the capital flow into the Trenčín Region and the effectiveness of the enterprises and businesses did not bring such dynamics in the regional GDP to approach the average Slovak level.

The regional self-government in the Trenčín Region is advised to focus on coordinating and directing the economic structure so that the higher added value can be created in some favoured industries.

\section{References}

Adamkovičová, B. (2013). Regionálne analýzy a plánovanie. Trenčín: FSEV TnUAD, ISBN 978-80-8075575-1

Bendavid-Val, A. (1991). Regional and Local Economic Analysis for Practitioners. USA: PRAEGER, 1991, 264 p., ISBN 027-593-520-5

Bielik, P. (2008). Konkurencieschopnost' a ekonomický rast: Európske a národné perspektívy. In: Zborník Medzinárodné vedecké dni 2008, Nitra: SPU, ISBN 978-80-552-0060-6

Blair, J. P. (1995). Local Economic Development Analysis and Practice. USA: SAGE Publications, 345 s., ISBN 0-80-39-5376-3

Fáziková, M., Lacina, P., Stehlíková, B. (2003). Súčasné problémy rozvoja vidieckeho priestoru na Slovensku. Záverečná správa výskumného projektu VEGA 1/7665/20, Nitra: SPU

Habánik, J., Masárová, J. (2013). Zmeny v odvetvovej štruktúre ekonomiky SR. In: Sociálno-ekonomická revue. Vedecký časopis Fakulty sociálno-ekonomických vztahov, Trenčianska univerzita Alexandra Dubčeka v Trenčine, čislo 2/2013, ročnik 11, str. 71. Trenčín: FSEV, TnUAD v Trenčín, ISSN-13363727

Ivanová, E. (2011). Vybrané otázky regionálneho rozvoja v SR s dôrazom na regionálne disparity. In: Sociálno-ekonomická revue. Vedecký časopis Fakulty sociálno-ekonomických vztahov, Trenčianska univerzita Alexandra Dubčeka v Trenčíne, čislo 2/2011, ročník 9, str. 27. Trenčín: FSEV, TnUAD v Trenčin, ISSN-1336-3727

Gajdoš, P. (2001). K vybraným problémom transformácie sociálno-priestorovej situácie Slovenska v 90-tych rokoch. Sociológia, 33, č. 2

Kačírková, M. (2005). Regionálne a odvetvové špecifiká transformácie podnikovej sféry. Zmena kvality podnikatel'ského prostredia. In: Morvay, K. et al.: Transformácia ekonomiky: skúsenosti Slovenska. Bratislava: Ústav slovenskej a svetovej ekonomiky SAV, ISBN 80-7144-143-0 
Králiková, K. (2006). K niektorým vybraným inštitútom rozpočtového hospodárenia obcí. In: Jak úspěšně podnikat v přihraničnich regionech jihovýchodni Moravy. Sborník. II. Mezinárodní konference 2006. 1. vyd. Kunovice : Evropský polytechnický institut, 2006, s.105-111. ISBN 80-7314-097-7

Maier, G., Tödtling, F. (1998). Regionálna a urbanistická ekonomika - Regionálny rozvoj a regionálna politika. Bratislava: Elita, 320 s. ISBN 80-8044-049-2

Morvay, K., Azudová, L., Hoffmann, P., Juríčková, V., Kačírková, M., Okáli, I., Páleník, V., Petrík, B., Vokoun, J., Žárska, E. (2005). Transformácia ekonomiky: skúsenosti Slovenska. Bratislava: Ústav slovenskej a svetovej ekonomiky SAV, ISBN 80-7144-143-0

Okáli, I., Gabrielová, H., Morvay, K. (1999). Zhodnotenie doterajších výsledkov transformačného procesu v slovenskej ekonomike, náčrt jeho otvorených problémov a d’alšieho postupu z hl'adiska úloh hospodárskej ekonomiky. Bratislava: Ústav slovenskej a svetovej ekonomiky SAV, $110 \mathrm{~s}$.

Richardson, H. W. (1979). Regional Economics. USA: University of Ilinois Press, 1979, 325 p. ISBN 0-25200748-4 